\title{
EFEKTIVITAS MODEL EVERYONE IS A TEACHER HERE (ETH) DALAM MENINGKATKAN KEMANDIRIAN BELAJAR DAN KEMAMPUAN KOMUNIKASI MATEMATIKA SISWA KELAS XI
}

\section{EFFECTIVENESS OF LEARNING MODEL OF COOPERATIVE LEARNING TYPE EVERYONE IS A TEACHER HERE (ETH) IN IMPROVING LEARNING LEARNING AND COMMUNICATION STUDY OF MATHEMATICS STUDENT CLASS XI}

\author{
Amral $^{1}$, Usman Mulbar ${ }^{2}$, Ilham Minggi ${ }^{3}$ \\ ${ }^{1,2,3}$ Prodi Pendidikan Matematika PPs UNM, Makassar, Indonesia \\ amral_anastasia@yahoo.co.id ${ }^{1}$
}

\begin{abstract}
The purpose of this study is to describe the effectiveness of cooperative learning model Type Everyone is A Teacher Here (ETH) in learning mathematics on circumference and perimeter of twodimentional figure material in class XI SMKT Somba Opu Sungguminasa Kab. Gowa and describes learning outcomes, responses, activities, learning independence, and students' mathematical communication skills through the implementation of cooperative learning model type Everyone is $A$ Teacher Here (ETH). This type of research is a pre-experiment research involving one class (One Group) as an experimental class, with sample selection using Simple Random Sampling technique. The results showed that the implementation of cooperative learning model type Everyone is $A$ Teacher Here (ETH) on the material and Area Width of Flat in the category well done. Implementation of ETH type of cooperative learning model on mobile material and Broadband Building in grade XI SMKT Somba Opu Sungguminasa Kab. Gowa is effectively reviewed from aspects of learning outcomes, learning activities, responses, mathematical communication skills and student learning independence.
\end{abstract}

Keywords: ETH, Mathematics Communication, Learning Independence

Abstrak

Tujuan penelitian ini untuk mendeskripsikan keefektifan model pembelajaran kooperatif tipe Everyone is A Teacher Here (ETH) dalam pembelajaran matematika materi Keliling dan Luas Bangun Datar pada kelas XI SMKT Somba Opu Sungguminasa Kab. Gowa dan mendeskripsikan hasil belajar, respon, aktivitas, kemandirian belajar, dan kemampuan komunikasi matematika siswa melalui penerapan model pembelajaran kooperatif tipe Everyone is A Teacher Here (ETH). Jenis penelitian ini adalah penelitian pra-eksperimen yang melibatkan satu kelas (One Grup) sebagai kelas eksperimen, dengan pemilihan sampelmenggunakan teknik Simple Random Sampling.Hasil penelitian menunjukkan bahwa keterlaksanaan model pembelajaran kooperatif tipe Everyone is a Teacher Here (ETH)pada materi Keliling dan Luas Bangun Datardalam kategori terlaksana dengan baik. Penerapan model pembelajaran kooperatif tipe ETHpada materi Keliling dan Luas Bangun Datar pada siswa kelas XI SMKT Somba Opu Sungguminasa Kab. Gowa efektif ditinjau dari aspek hasil belajar, aktivitas belajar, respon, kemampuan komunikasi matematika dan kemandirian belajar siswa.

Kata Kunci: ETH, Komunikasi Matematika, Kemandirian Belajar.

\section{PENDAHULUAN}

Matematika adalah mata pelajaran yang diajarkan pada setiap jenjang pendidikan baik di SD, SMP, SMA/SMK maupun perguruan tinggi. Pada proses pembelajaran, mata pelajaran matematika dikenal memiliki 
konsep-konsep yang memerlukan aktivitas yang cukup untuk mempelajari dan memahaminya karena konsep tersebut umumnya bersifat abstrak [1]. Selain itu matematika juga merupakan sarana berpikir logis, analitis, dan sistematis, oleh karena itu matematika memegang peran penting dalam usaha perkembangan ilmu dan teknologi. Perkembangan ilmu dan teknologi diikuti dengan perkembangan model pembelajaran termasuk model pembelajaran kooperatif [2].

Menurut Ref. [3] menyatakan bahwa model pembelajaran kooperatif merupakan suatu model pembelajaran dimana sistem belajar dan bekerja dalam kelompokkelompok kecil yang berjumlah 4-6 orang secara kolaboratif sehingga dapat merangsang siswa lebih bersemangat dalam belajar. Agar siswa dapat bersemangat dalam belajar, diperlukan sebuah strategi yang mudah digunakan dalam pembelajaran, salah satunya dengan penggunaan strategi Everyone is a Teacher Here (ETH). ETH merupakan sebuah strategi yang mudah, guna memperoleh partisipasi kelas yang keseluruhan dan tanggung jawab secara individu.Strategi ini memberikan kesempatan pada setiap siswa untuk bertindak sebagai seorang "pengajar" terhadap siswa lain. Dengan strategi ini, siswa yang selama ini tidak mau terlibat akan ikut serta dalam pembelajaran secara aktif [4].

Menurut Mujiamn dalam Ref. [5] kemandirianbelajar adalah berperilaku aktif yang didorong oleh niat atau motif untuk menguasai suatu masalah, dibangun dengan bekal pengetahuan atau kompetensi yang dimiliki, baik dalam menetapkan waktu belajar, tempat belajar, irama belajar, tempo belajar, cara belajar, maupun evaluasi belajar yang dilakukan oleh pembelajaran sendiri. Menurut penelitian Ref. [6] menyebutkan beberapa indikator kemandirian belajar diantaranya (1) percaya diri, (2) tidak menyandarkan diri pada orang lain, (3) mau berbuat sendiri, (4) bertanggung jawab, (5) ingin berprestasi tinggi, (6) menggunakan pertimbangan rasional dalam memberikan penilaian, mengambil keputusan, dan memecahkan masalah, serta menginginkan rasa bebas, dan (7) selalu mempunyai gagasan baru.

Berdasarkan hasil observasi dan wawancara peneliti dengan guru mata pelajara nmatematika pada kelas XI TKJ SMKT Somba Opu Sungguminasa Kabupaten Gowa diperolehinformasi bahwa kemampuan komunikasi matematika sebagian siswa masih tergolong rendah, terutama pada materigeometri. Komunikasi matematis menurut Ref. [7] dapat diartikan sebagai suatu peristiwa dialog atau saling hubungan yang terjadi di lingkungan kelas, di mana terjadi pengalihan dan pesan yang dialihkan berisikan tentang materi matematikayang dipelajari siswa, misalnya berupa konsep, rumus atau startegi penyelesaian suatu masalah.Materi keliling dan luas bangun datar merupakan salah satu materi geometri yang diajarkan di SMK kelas XI TKJ. Kemampuan beberapa siswa dalam memahami soal atau permasalahan yang diberikan masih kurang karena mereka tidak terbiasa menuliskan apa yang diketahui dan apa yang ditanyakan dari soal tersebut. Beberapa siswa juga mengalami kesulitan dalam menginterpretasikan suatu permasalahan dalam bentuk grafik, gambar, maupun tabel. Selain itu siswa juga kesulitan dalam menentukan langkah yang runtut karena mereka kurang memahami konsep matematika yang telah dimiliki. Serta diperoleh informasi bahwa beberapa siswa masih belum mempunyai kesadaran dan tanggung jawab untuk belajar, mereka hanya mau belajar jika ada tugas atau akan ulangan saja dan masih ada sebagian siswa yang mencontoh jawaban tugas dari temannya dan mencontek saat ujian. Hal ini menunjukkan sebagian siswanya masih kurang dalam hal kemandirian belajar dan berdasarkan observasi bahwa nilai rata-rata hasil belajar matematika siswa kelas XI TKJ SMKT Somba Opu Sungguminasa Kabupaten Gowa tahun pelajaran 2015-2016 semester genap hanya mencapai 62.00 masih di bawah 
Kriteria Ketuntasan Minimal (KKM) yang ditetapkan di sekolah tersebut yaitu 75.00 dari skor ideal 100.

\section{METODE PENELITIAN}

Penelitian ini adalah penelitian praeksperimen yang melibatkan satu kelas (One Grup) sebagai kelas eksprimen atau kelas perlakuan (treatment). Penelitian ini untuk mendeskripsikan hasil belajar siswa, aktivitas siswa, respons siswa, kemandirian belajar dan kemampuan komunikasi matematika melalui Penerapan Model Pembelajaran Kooperatif tipe Everyone is A Teacher Here (ETH) pada siswa kelas XI TKJ. Lokasi Penelitian bertempat di SMKT Somba Opu Sungguminasa Kabupaten Gowa. Populasi dalam penelitian ini adalah seluruhsiswa kelas XI SMKT Somba Opu Sungguminasa Kabupaten Gowa yang berjumlah 80 siswa dan tersebar pada empat kelas. Sampel penelitian terdiri dari satu kelas yakni kelas yang akan diberikan perlakuan melalui Penerapan Model Pembelajaran Kooperatif tipe Everyone is A Teacher Here (ETH).

Data hasil penelitian dianalisis dengan menggunakan statistik deskriptif dan inferensial. Analisis deskriptif dilakukan dengan menggambarkan data hasil penelitian yang diperoleh, dan Uji inferensial yang digunakan dengan taraf signifikan 0.05 adalah Uji One Sample T-testuntuk mengetahui keefektifan model pembelajaran kooperatif tipe Everyone is A Teacher Here (ETH) dan uji $\mathrm{Z}$ untuk menentukan keefektifan ketuntasan klasikal kelas.

\section{HASIL PENELITIAN}

\section{Hasil Analisis Deskriptif}

Data aktivitas siswa yang diperoleh dari hasil pengamatan pada setiap pertemuan dengan menggunakan rubrik. Data yang diperoleh dari instrumen tersebut dirangkum pada setiap akhir pertemuan. Hasil rangkuman setiap observasi disajikan pada tabel berikut. Data hasil respons siswa terhadap pembelajaran dengan model pembelajaran kooperatif tipe Everyone is A Teacher Here adalah cenderung positif dengan rata-rata 3.52. Dengan demikian dapat disimpulkan bahwa respons siswa terhadap model pembelajaran. Kooperatif tipe Everyone is A Teacher Here (ETH) secara deskriptif memenuhi kriteria keefektifan.

Berdasarkan hasil data kemampuan komunikasi siswa setelah diajar dengan model pembelajaran kooperatif tipe Everyone is A Teacher Here dengan ratarata 0.61 berada pada klasifikasi sedang. Hal ini menunjukkan bahwa peningkatan kemampuan komunikasi matematika setelah diajar dengan model pembelajaran kooperatif tipe Everyone is A Teacher Here pada siswa kelas XI TKJ Somba Opu Sungguminasa Kab. Gowa lebih besar dari 0.29. Berdasarkan hasil data kemandirian belajar siswa setelah diajar dengan model pembelajaran kooperatif tipe Everyone is A Teacher Here dengan rata-rata 0.40 berada pada klasifikasi sedang. Hal ini menunjukkan bahwa peningkatan kemandirian belajar matematika setelah diajar dengan model pembelajaran kooperatif tipe Everyone is A Teacher Here pada siswa kelas XI TKJ Somba Opu Sungguminasa Kab. Gowa lebih besar dari 0.29

\section{Hasil Analisis Inferensial}

Berdasarkan hasil data kemampuan komunikasi matematika siswa tampak bahwa signifikansi $P($ sig. $(2$-tailed $))=$ 0.000 dari jumlah siswa 20 orang, $P$-value $<\alpha$ yaitu $0.000<0.05$. Karena pengujian rata rata hasil gain ternormalisasi di kelas XI TKJ dilakukan dengan Uji $\mathrm{t}$ satu sampel (One Sample T-Test), maka hasil Uji $t$ satu sampel pada data gain menunjukkan bahwa $\frac{p \text {-value (two tailed) }}{2}<\alpha=0.05$ maka $\mathrm{H}_{0}$ ditolak. Hal ini menunjukan bahwa ratarata gain ternormalisasi kemampuan komunikasi matematika siswa pada kelas XI TKJ yang diajar melalui model pembelajaran kooperatif tipe Everyone is 
Efektivitas Model Everyone Is A Teacher Here (ETH) dalam Meningkatkan Kemandirian Belajar dan Kemampuan Komunikasi Matematika Siswa Kelas XI

A Teacher Here lebih besar dari 0.29 (Kategori Minimal Sedang). Sedangkan Berdasarkan Uji Normalitas ShapiroWilk, maka signifikansi atau $P$-value $=$ 0.232 untuk Pre-Test, signifikansi $P$ value untuk Post-Test $=0.157 \mathrm{dan}$ signifikansi $P$-value untuk Gain $=0.131$ dari 20 orang siswa. Karena $P$-value PreTest $=0.232>\alpha, P$-value Post-Test $=$ $0.157>\alpha$, dan $P$-value gain $=0.131>\alpha$. Ini berarti bahwa data berdistribusi normal, dengan demikian Uji-t dapat diterapkan.

Berdasarkan hasil data kemandirian belajar siswa tampak bahwa signifikansi $P($ sig.(2-tailed $))=0.037$ dari jumlah siswa 20 orang, $P$-value $<\alpha$ yaitu $0.037<$ 0.05. Karena pengujian rata rata hasil gain ternormalisasi di kelas XI TKJ dilakukan dengan Uji t satu sampel (One Sample T-Test), maka hasil Uji t satu sampel pada data gain menunjukkan bahwa $\frac{p \text {-value (two tailed) }}{2}<\alpha=0.05$ maka $\mathrm{H}_{0}$ ditolak. Hal ini menunjukan bahwa rata-rata gain ternormalisasi kemandirian belajar matematika siswa pada kelas XI TKJ yang diajar melalui model pembelajaran kooperatif tipe Everyone is A Teacher Here lebih besar dari 0.29 (Kategori Minimal Sedang). Sedangkan Berdasarkan Uji Normalitas Shapiro-Wilk, maka signifikansi atau $P$ value $=0.363$ untuk Pre-Test, signifikansi $P$-value untuk Post-Test $=0.082$ dan signifikansi $P$-value untuk Gain $=0.556$ dari 20 orang siswa. Karena $P$-value PreTest $=0.363>\alpha, P$-value Post-Test $=$ $0.082>\alpha$, dan $P$-value gain $=0.556>\alpha$. Ini berarti bahwa data berdistribusi normal, dengan demikian Uji-t dapat diterapkan.

Tabel 1. Skor Indikator Keefektifan Secara Holistik Pada Kelas XI TKJ

\begin{tabular}{|c|c|c|c|c|}
\hline $\begin{array}{c}\text { Model } \\
\text { Pembelajaran }\end{array}$ & Indikator & Kriteria & Pencapaian & Keputusan \\
\hline \multirow{4}{*}{$\begin{array}{l}\text { Kooperatif tipe } \\
\text { Everyone is A } \\
\text { Teacher Here } \\
\text { (ETH) }\end{array}$} & 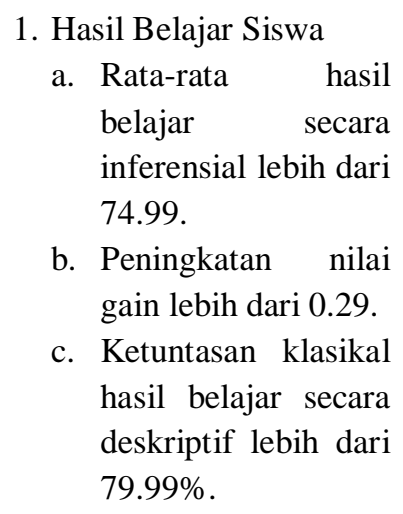 & $\mu_{\mathrm{g}}>0.29$ & $\begin{array}{c}\text { Kategori } \\
\text { Tinggi } \\
\left(\mu_{\mathrm{g}}=0.80\right) \\
\pi=90 \%\end{array}$ & Terpenuhi \\
\hline & 2. Aktivitas Siswa & $\begin{array}{c}\text { Minimal } \\
\text { Kategori } \\
\text { Aktif }\end{array}$ & Kategori Aktif & Terpenuhi \\
\hline & 3. Respons Siswa & $\begin{array}{l}\text { Minimal } \\
\text { Kateogri } \\
\text { Posistif }\end{array}$ & $\begin{array}{l}\text { Kategori } \\
\text { Positif }\end{array}$ & Terpenuhi \\
\hline & $\begin{array}{ll}\text { 4. } & \text { Kemampuan } \\
& \text { Komunikasi } \\
& \text { Matematika Siswa }\end{array}$ & $\mu_{\mathrm{g}}>0.29$ & $\begin{array}{c}\text { Kategori } \\
\text { Sedang } \\
\left(\mu_{\mathrm{g}}=0.61\right)\end{array}$ & Terpenuhi \\
\hline
\end{tabular}




$\begin{array}{lllcl}\text { 5. Kemandirian } & \text { Belajar } & \mu_{\mathrm{g}}>0.29 & \begin{array}{c}\text { Kategori } \\ \text { Sedang } \\ \left(\mu_{\mathrm{g}}=0.40\right)\end{array} & \text { Terpenuhi } \\ \text { Siswa } & & & \end{array}$

\section{PEMBAHASAN}

\section{Keterlaksanaan Model Pembelajaran}

Berdasarkan hasil penelitian pada aspek keterlaksanaan model untuk kedua model pembelajaran yaitu model pembelajaran kooperatif tipe Everyone is A Teacher Here, diperoleh fakta bahwa pada model pembelajaran kooperatif tipe Everyone is A Teacher Here rata-rata keterlaksanaan model adalah 4.36 (kategori terlaksana dengan baik). Data tersebut menunjukkan bahwa keterlaksanaan model pembelajaran tersebut terlaksana dengan baik.

\section{Aktivitas Siswa}

Hasil pengamatan observer terhadap aktivitas siswa terhadap pembelajaran kooperatif tipe Everyone is A Teacher Here pada kelas XI TKJ, menunjukkan bahwa dari ke lima belas aspek yang diamati, ada 5 aspek yang memenuhi kategori sangat baik dan 10 aspek yang memenuhi kategori baik. Hasil penelitian ini juga memperkuat pendapat Ref. [8] yang memaparkan pengertian model pembelajaran kooperatif merupakan suatu model pembelajaran dimana sistem belajar dan bekerja dalam kelompok- kelompok kecil yang berjumlah 4-6 orang secara kolaboratif sehingga dapat merangsang siswa lebih bergairah dalam belajar.

\section{Hasil Pengamatan terhadap Respons Siswa}

Berdasarkan hasil angket respons siswa, secara keseluruhan memberi respons siswa positif terhadap pembelajaran. pada pembelajaran kooperatif tipe Everyone is $A$ Teacher Here diperoleh nilai 3.6 termasuk dalam kategori positif. Perolehan respons siswa telah memenuhi kriteria keefektifan yaitu rata-rata respons siswa setiap aspek berada pada kategori $\geq 3.5$. Artinya hampir seluruh siswa memberikan respons positif terhadap kedua model pembelajaran tersebut. Sehingga demikian, dilihat dari besarnya respons siswa melalui pembelajaran kooperatif tipe Everyone is A Teacher Here lebih baik.Hasil penelitian ini sejalan dengan pendapat Ref. [7] yang mengemukakan bahwa konsekuen yang menyenangkan akan bertambah frekuensinya atau perangsang dalam melakukan perbuatan, maka ia akan menjadi giat belajar.

\section{Hasil Belajar Siswa}

Hasil analisis data terlihat bahwa kemampuan siswa dalam pembelajaran matematika yang diperoleh melalui tes awal sebelum dimulainya pembelajaran dan tes akhir setelah pembelajaran melalui model pembelajaran kooperatif tipe Everyone is A Teacher Here mengalami peningkatan dari kategori rendah diawal pembelajaran dan berada pada kategori tinggi dan sedang setelah pembelajaran kooperatif tipe Everyone is A Teacher Here diperoleh nilai rata-rata hasil belajar siswa adalah 84.09 atau berada pada kategori tinggi.

\section{Hasil Kemampuan Komunikasi Matematika Siswa}

Dari hasil analisis data terlihat bahwa rata-rata kemampuan komunikasi matematika siswa yang diperoleh melalui tes awal sebelum dimulainya pembelajaran sebesar 38.60 berada pada kategori sangat rendah, sedangkan tes akhir setelah pembelajaran dengan menggunakan model pembelajaran kooperatif tipe Everyone is $A$ Teacher Here(ETH) sebesar 75.83 berada pada kategori tinggi, serta nilai gain ternormalisasi dengn model pembelajaran kooperatif tipe Everyone is A Teacher Here adalah 0.61 berada dalam kategori sedang. Hal ini menunjukkan bahwa kemampuan komunikasi matematika siswa pada 
Efektivitas Model Everyone Is A Teacher Here (ETH) dalam Meningkatkan Kemandirian Belajar dan Kemampuan Komunikasi Matematika Siswa Kelas XI

pembelajaran kooperatif tipe Everyone is $A$ Teacher Here (ETH) adalah berada pada kategori tinggi.

\section{Hasil Kemandirian Belajar Siswa}

Peningkatan kemandirian belajar siswa kelas XI TKJ Somba Opu Sungguminasa Kab. Gowa dapat diketahui dari hasil ratarata angket kemandirian belajar, baik sebelum maupun sesudah diberi model pembelajaran kooperatif tipe Everyone is $A$ Teacher Here (ETH). Sebelum diberikan perlakuan, diperoleh hasil sebesar $66.3 \%$ (kriteria baik) dan setelah diberikan perlakuan, diperoleh hasil $79.9 \%$ (kriteria sangat baik) serta rata-rata gain pada kemandirian belajar diperoleh siswa sebesar 0.40 (Kategori Sedang).

\section{KESIMPULAN}

Adapun kesimpulan yang dapat ditarik dari penelitian ini adalah Pembelajaran dengan menggunakan model pembelajaran kooperatif tipe Everyone is A Teacher Here (ETH) efektif diterapkan di kelas XI Somba Opu Sungguminasa Kab. Gowa materi Keliling dan Luas Bangun Datar. Adapun indikator keefektifan yaitu (1) hasil belajar siswa, (2) aktivitas siswa dalam pembelajaran, (3) respons siswa terhadap pembelajaran, (4) kemandirian belajar, dan (5) kemampuan komunikasi matematika. Kesimpulan ini didukung oleh pencapaian keefektifan antara lain:

1. Hasil belajar matematika siswa kelas XI SMKT Somba Opu Sungguminasa Kab. Gowa setelah diterapkan pembelajaran kooperatif tipe Everyone is A Teacher Here (ETH) menunjukkan persentase ketuntasan siswa secara klasikal mencapai $90.00 \%$, artinya ketuntasan hasil belajar secara klasikal tercapai. Skor rata-rata posttest siswa setelah diajar lebih besar dari 74.99 (KKM) yaitu 84.09. Selain itu, nilai rata-rata gain ternormalisasi siswa lebih dari 0.29 yaitu sebesar 0.80 yang berada pada kategori tinggi. Sehingga dapat disimpulkan bahwa hasil belajar siswa dengan pembelajaran kooperatif tipe Everyone is A Teacher Here (ETH) dapat dikategorikan efektif.

2. Skor rata-rata aktivitas siswa pada aktivitas siswa pada pembelajaran kooperatif tipe Everyone is A Teacher Here (ETH) dikatakan efektif yaitu sebesar 3.4 termasuk dalam kategori baik.

3. Skor rata-rata respon siswa terhadap pembelajaran kooperatif tipe Everyone is A Teacher Here (ETH) adalah 3.52 atau berada dalam kategori positif. Sehingga dapat disimpulkan bahwa rata-rata respon siswa pada pembelajaran kooperatif tipe Everyone is A Teacher Here (ETH) dapat dikategorikan efektif.

4. Skor kemampuan komunikasi matematika siswa kelas XI SMKT Somba Opu Sungguminasa Kab. Gowa setelah diterapkan pembelajaran kooperatif tipe Everyone is A Teacher Here (ETH) menunjukkan nilai rata-rata gain ternormalisasi siswa lebih dari 0.29 yatiu sebesar 0.61 yang berada pada kategori sedang. Sehingga dapat disimpulkan bahwa kemampuan komunikasi matematika siswa dengan pembelajaran kooperatif tipe Everyone is A Teacher Here (ETH) dapat dikategorikan efektif.

5. Skor kemandirian belajar siswa kelas XI SMKT Somba Opu Sungguminasa Kab. Gowa setelah diterapkan pembelajaran kooperatif tipe Everyone is A Teacher Here (ETH) menunjukkan nilai rata-rata gain ternormalisasi siswa lebih dari 0.29 yaitu sebesar 0.40 yang berada pada kategori sedang. Sehingga dapat disimpulkan bahwa kemandirian belajar siswa dengan pembelajaran kooperatif tipe Everyone is A Teacher Here (ETH) dapat dikategorikan efektif. 


\section{DAFTAR PUSTAKA}

[1]. Rusman. 2013. Model-Model Pembelajaran Mengembangkan

[2]. Suprijono, Agus. 2013. Cooperatif Learning Teori \& Aplikasi PAIKEM. Yogyakarta: Pustaka Pelajar.

[3]. Slavin, Robert. E. 2010. Cooperatif Learning Teori, Riset dan Praktek. Bandung: Nusa Medfia.

[4]. Silberman, Melvin L. 2013. Active Learning: 101 Cara Belajar Siswa Aktif. Bandung: Nuansa Cendekia.

[5]. Nurhayati, Eti. 2011. Psikologi Pendidikan inovatif. Yogyakarta: Pusta Pelajar.

[6]. Eko, B. \& Kharisudin, I. 2010. Improving the Autodidact Learning of Student On Kalkulus Through Cooperative Learning "Student Teams Acievement Division" By Portofolio Programed. Jurnal Penelitian Pendidikan, 27(1): 78-83. Tersedia di http://journal.unnes.ac.id [Diaskses 01-09-2016].

[7]. Susanto, Ahmad. 2013. Teori Belajar dan Pembelajaran di Sekolah Dasar. Jakarta: Prenadamedia Group.

[8] Slameto. 2010. Belajar dan FaktorFaktor yang Mempengaruhinya. Jakarta: Rineka Cipta. 